Portland State University

PDXScholar

Summer 9-20-2013

\title{
Increasing Evidence Based Reasoning in an 8th Grade Classroom Through Explicit Instruction
}

Erol Chandler

Portland State University

Follow this and additional works at: https://pdxscholar.library.pdx.edu/open_access_etds

Part of the Educational Methods Commons, and the Science and Mathematics Education Commons Let us know how access to this document benefits you.

\section{Recommended Citation}

Chandler, Erol, "Increasing Evidence Based Reasoning in an 8th Grade Classroom Through Explicit Instruction" (2013). Dissertations and Theses. Paper 1474.

https://doi.org/10.15760/etd.1473

This Thesis is brought to you for free and open access. It has been accepted for inclusion in Dissertations and Theses by an authorized administrator of PDXScholar. Please contact us if we can make this document more accessible: pdxscholar@pdx.edu. 
Increasing Evidence Based Reasoning in an $8^{\text {th }}$ Grade Classroom

Through Explicit Instruction

by

Erol Chandler

A thesis submitted in partial fulfillment of the requirements for the degree of

Master of Science

in

Science Teaching

Thesis Committee:

Liza Finkel

Michael Cummings Michael Flower

Portland State University 201 


\begin{abstract}
This study investigates the effectiveness of an instructional strategy that uses students' prior understanding of informal evidence based reasoning (EBR) to build an understanding of scientific EBR. A pre and post instructional strategy survey revealed that students' understanding of EBR increased over the length of the study. Data collected from pre and post instructional discussions also showed increases in the amount of EBR students used.
\end{abstract}




\section{Table of Contents}

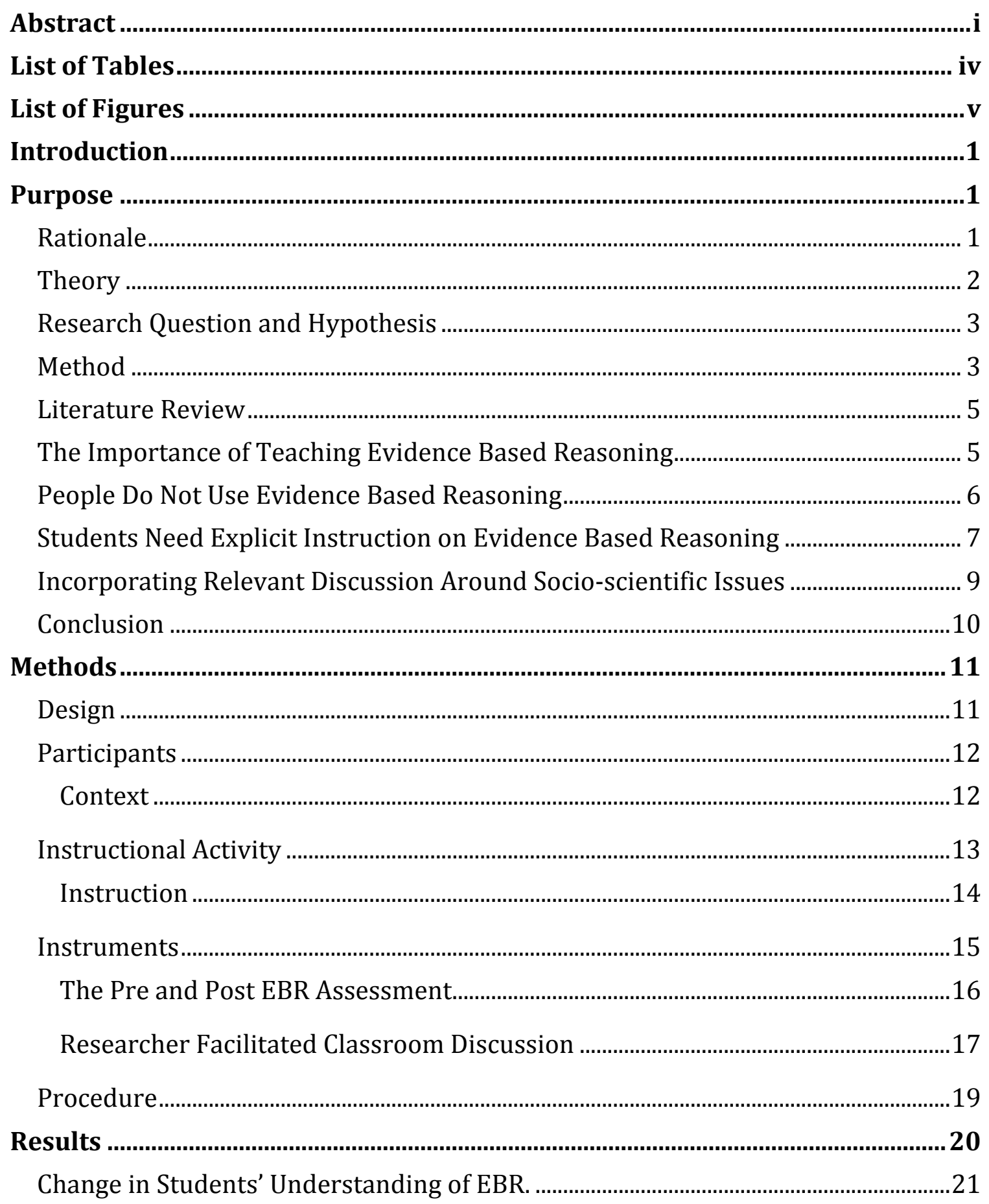


Change in the Amount of EBR Use in Discussion of SSIs ..............................................23

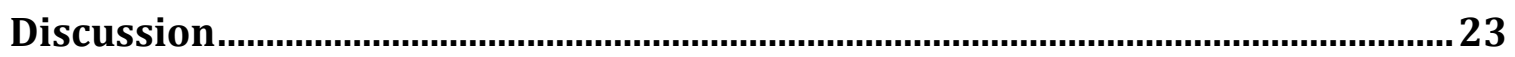

Increase in Student Understanding of EBR …………................................................23

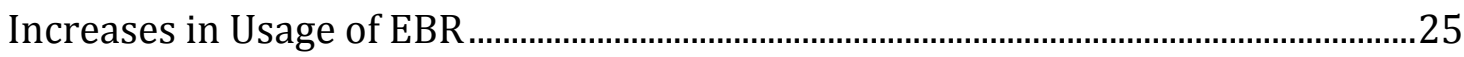

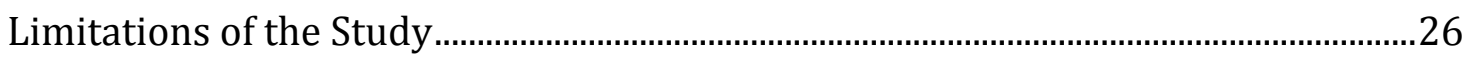

Recommendations for Future Research .......................................................................28

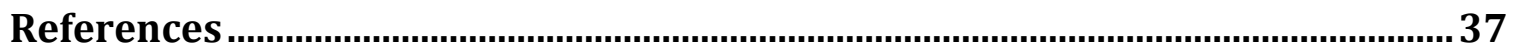

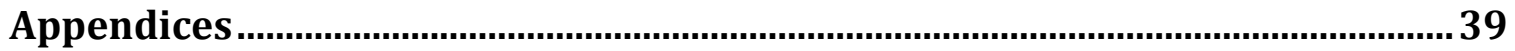

Appendix A: Evidence Based Reasoning Pre/Post Assessment ..................................39

Appendix B: Pre Teaching Strategy Discussion Topics ....................................................43

Appendix C: Evidence Based Reasoning Connection Sheet...........................................45

Appendix D: Teaching Strategy Presentation.................................................................46

Appendix E: Teaching Strategy Presentation Script.........................................................54

Appendix F: Post Teaching Strategy Discussion Topics ……………………………....57

Appendix G: HSRCC Review Exemption Form ……………………………......................59 


\section{List of Tables}

Table 1: Focus for Each Assessment Method Used in Study.............................................35

Table 2: Data Collected from Pre and Post Instructional Strategy Discussions ..........36 


\section{List of Figures}

Figure 1: Students Responses to Individual Pre and Post Assessment .............30

Figure 2: Percent Change in Class Averaged Pre and Post Assessment ...........31

Figure 3: Themed Student Understanding Gains ..........................................32

Figure 4: Informative Student Responses.....................................................33

Figure 5: Type of Student Responses During Discussions...............................34 


\section{Introduction}

\section{Purpose}

The purpose of this study is to increase middle school students' understanding of and ability to use evidence based reasoning (EBR) in science. Educating students to use processes that can lead to good choices is important as they move into their roles as participating members of a democratic citizenry. This research study examines the effectiveness of an instructional strategy designed to help students acquire a skill that will serve them throughout their lives.

\section{Rationale}

The basis of good decision, argument, or opinion is logical reasoning that is supported by evidence. Reasoning using evidence is the heart of scientific literacy and, arguably, science itself. As outlined in the National Science Education Standards (National Research Council, 1996), "an explicit goal of the National Science Education Standards is to establish high levels of scientific literacy in the United States (National Research Council, 1996)." In fact, EBR is embedded in the most reliable fundamental process science uses: the scientific method. Reasoning and evidence are used in creating a hypothesis, observing and building evidence, and drawing a conclusion is often effectively stating a claim. 
The National Science Education Standard's emphasis on increasing the use of EBR is driven by its importance as a daily skill in a democracy. EBR is crucial in many decisions, from simple everyday choices such as deciding to put a jacket on in cold weather, to high-level political decisions that can change the lives of countless people.

With such a focus on EBR, it is surprising to find that students do not voluntarily do much EBR in the classroom (Ruiz-Primo et al, 2010). Even among university professors from various backgrounds, very little EBR is used when defending their personal opinions and decisions (Bell, 2003). If getting students and people to become scientifically literate is the goal, it is clear that the need to educate students about how to do EBR is paramount.

\section{Theory}

To create a lesson designed to increase students' ability to use EBR in and out of school settings, this study drew on two educational learning theories. First, this study used insights from Vygotsky's educational development theory, zones of proximal development, for inspiration in structuring a lesson that tapped students' own knowledge as a foundation on which to build new knowledge (Berk et al, 1995). The goal of the EBR connection sheet (Appendix C, and part of the lesson) was to allow students to use their own experiences as scaffolds for the new understanding of scientific EBR that was brought to their attention in the lesson. Students accomplished this by identifying the EBR used in their own 
lives, then, through individual work, group discussion, and guidance from the teacher and researcher, they made connections to more scientific EBR.

Second, large group discussions, inspired by Osborne's (2010) assertion that argumentation can be used as a way for students to practice and enhance EBR skills (2010) were used to give students a chance to practice and demonstrate their ability to use EBR when discussing scientific issues. Using socio-scientific issues (SSI) as the subject of these discussions kept student learning relevant and content based, another factor that has been demonstrated to be instrumental in student learning (Cavagnetto 2010, Zeidler, 2009).

\section{Research Question and Hypothesis}

Does an instructional strategy that explicitly builds on students' informal EBR help students gain understanding of EBR and increase usage of scientific EBR during discussion in the science classroom?

The expectation of this study is "yes." If students are taught EBR using an instructional strategy that explicitly builds on their prior EBR knowledge, students can gain understanding and increase their usage of scientific EBR during discussion in the science classroom.

\section{Method}

The researcher constructed a pre EBR questionnaire (Appendix A) to assess $8^{\text {th }}$ grade students' familiarity and understanding of EBR and its components. Then in order to gather initial data on students' ability to use EBR 
in science, students participated in a large group discussion that was facilitated by the researcher and audio recorded. During this discussion, students talked about two case studies (Appendix C) that were focused on the ethics surrounding genetics; this occurred as students were finishing a unit on genetics and heredity. A few days after the first discussion, the researcher taught a lesson designed to help them understand the connections between informal everyday EBR and formal scientific EBR. Each student filled out a Connection Sheet (Appendix D) during the lesson to help them in brainstorming and documenting their claims, reasoning, and evidence. A second recorded discussion about two different genetic case studies (Appendix F) was later facilitated in the classroom to gather comparison data on the amount of EBR students produce during discussion. To conclude gathering data, seven days later a post EBR assessment (Appendix A) was administered to each student. 


\section{Literature Review}

The literature review is divided into three subsections in order to situate this study in the research. The first section highlights the need for students to use EBR and be scientifically literate. The second section brings to light the amount of EBR that individuals voluntarily do in school and outside of it, suggesting there is much room for improvement. Finally, the case for how to teach EBR is laid out followed by a review of research describing how to make material relevant for students through the use of socio-scientific issues and discussion.

\section{The Importance of Teaching Evidence Based Reasoning}

Scientific literacy, as defined in the National Science Education Standards includes "understanding of the nature of science, the scientific enterprise, and the role of science in society and personal life" (National Research Council, 1996) as a strong component. In other words, understanding science as a way of knowing is what can effectively help individuals become scientifically literate. EBR plays a crucial role in this aspect of scientific literacy. The standards suggest using science as a way of knowing through "...logical argument, and skeptical review" (National Research Council, 1996). EBR is deeply embedded in scientific argumentation and skeptical review, as is it at the heart of well-supported opinions and decisions. In science, when a claim is made, EBR is the process used to make it. 
The newest national science standards, the Next Generation Science Standards (National Research Council, 2011), even more directly highlight the need for students to be taught scientific reasoning. They discuss scientific literacy on a societal level citing the increasing need for a populace who are able to make well reasoned and evidence based decisions (National Research Council, 2011).

These two sets of standards support the assertion that EBR is at the heart of the nature of science as a process for inquiry and understanding of the world. As Christensen (2001) puts it, "Scientific literacy is about preparing future citizens to make personal and collective decisions on socio-scientific issues." Good evidence and sound reasoning is the key to making decisions.

\section{People Do Not Use Evidence Based Reasoning}

With the focus on the need for EBR, it is somewhat surprising to find out how little EBR people do, either voluntarily in a science classroom, or when making personal decisions. Bell et al (2003) analyzed written responses and recorded interviews of university professors from a range of disciplines to better understand their use of EBR. Bell found very little EBR used by professors from either the sciences or the humanities disciplines (Bell, 2003) when asked to defend their personal decisions. Another study conducted by Sadler et al (Sadler et al, 2005), studied the correlation between the type of reasoning done by individuals with high levels in genetics knowledge as compared with people with 
little genetics knowledge and also found very difference in their reasoning patterns.

Given the lack of EBR shown by adults (and even professionals) it may not be surprising that the case is not much different in the classroom with adolescents. When Ruiz-Promo et al (2010) analyzed student notebooks taken from an inquiry based middle school classroom they found that only $18 \%$ of students' explanations included a claim, evidence to support it and reasoning that linked the two.

Reasoning using evidence is extremely important to student success, in and out of the classroom. Students are expected by our society to grow into citizens that vote on important decisions revolving around large multifaceted issues such as climate change, or gun control. This reality comes in contrast to the fact the students do not voluntarily access a reliable decision making process, such as EBR, in the classroom, nor as in many of their decisions as adults. The message for future teacher is clear; they need to explicitly teach the process of EBR as a good way to make decisions or claims.

\section{Students Need Explicit Instruction on Evidence Based Reasoning}

Why students and the population at large do not use more EBR is open for debate. A study by Oulton et al (2004) suggests possible reasons, pointing out that the population may perceive science as a content area NOT as a way of processing information. To change this, the researchers recommend teachers 
focus on using real world situations in classrooms so that students can see the relevance of reasoning with evidence. They also suggest that teachers focus more on teaching the nature of scientific controversy than on just the content of the controversy. In other words, teachers who want to encourage EBR should prioritize teaching how to reason over the conclusions and content coming from reasoning (Oulton et al, 2004). Both of these suggestions were considered in this study.

One way to explicitly teach EBR would be to start with what students already know and understand and build new knowledge on that (Berk et al, 1995). Vgotsky's "Zones of Proximal Development" as outlined in Berk et al's study (1995) lays out the importance of starting the teaching of new knowledge by accessing similar knowledge that students already hold and use. Then, working outward from this prior knowledge students build connections between old and new knowledge to allow a proximal location for new knowledge to be stored.

Students use EBR every day, even if they do not recognize it as such, and this study aims to bring that EBR to light for students and then use it as the scaffold for new knowledge. For instance, a student may make a claim that you should put a coat on because it is November in the northwest and therefor cold. Whether they acknowledge it or not, they make this claim based on evidence (i.e. when it is cold you shiver and coats help to stop that; cold is uncomfortable to most humans, and therefore coats help that through insulation, etc) and sound 
reasoning. This kind of EBR is considered "informal" (Zeidler, 2009, Sadler, 2005) yet is built of many of the same components as the "formal" EBR scientists do. This study uses examples of informal EBR to help students understand the components of the process and then through worksheets and classroom instruction develops their ability to see the connections to formal EBR.

A meta-analysis study, (Smith, diSessa and Roschelle, 1994) supports the need to use scaffolding techniques to build on previous knowledge. The researchers reviewed approximately 70 studies to analyze student-learning gains when students built new knowledge on prior on prior knowledge. They found that it is difficult for students to build new information on a blank slate, and they posit that by using knowledge students already hold, teachers can increase student learning of new content.

The way students come to build new understanding of EBR and ability in using EBR is an important aspect of this study, but only one piece. Another very relevant aspect of the study is how students are to demonstrate using EBR.

\section{Incorporating Relevant Discussion Around Socio-scientific Issues}

Emulating real world EBR in the classroom is not easy to do. However, incorporating discussions of authentic issues is one strategy that has been suggested as a way to engage students in using evidence to support their positions (Michaels, 2008). Facilitated discussion of a content driven (content of a recent unit in the classroom) socio-scientific issue (SSI - a societal issue that 
has a scientific basis) can allow students to practice using EBR in a setting that most closely resembles the ways they may need to use EBR in their roles as citizens in a democratic society (Albert, 2009).

Creating an environment in which students feel comfortable speaking up and offering their reasoning and evidence is the ideal a teacher needs to shoot for when setting up a classroom for discussion (Michaels, 2008). Zeidler et al (2009) found that carefully chosen SSIs can serve as a "hook," leading to engagement and dramatic advancement in student reasoning.

Besides emulating real world experience, and being a "hook" for students, discussion based learning using social scientific issues has been shown to have great potential for increasing student learning (Bell 2003, Osborne, 2010, Oulton, 2004, Zohar, 2002, Sadler, 2005, Michaels, 2008)

Jack Holbrook and Miia Rannikmae (2007) argue that by using an "education through science" model, which emphasizes science content as a vehicle for learning, students can improve their reasoning skills, argumentation skills, and ability to make judgments. Their proposed model involves three steps and uses science as a tool to educate students on reasoning and social skills. First, a socio-scientific issue is argued and analyzed. Then students use science content to demonstrate evidence, and finally the process is reflected upon.

\section{Conclusion}


The research shows that although EBR has a strong connection to scientific literacy, it is not being portrayed by students or adults. Teachers need tools to teach the understanding of EBR and promote its use in the classroom to help future citizens use more EBR. Explicit teaching through scaffolding can support student learning, and this can be applied to teaching EBR. Incorporating content connected socio-scientific issues as the foundation of a class discussion makes EBR relevant to students by emulating real world scenarios, as well as incorporating what they are learning.

\section{Methods}

Incorporating the suggestions from previous research is essential when designing a study that creates an instructional strategy. For this study, the researcher designed a lesson that incorporates real world relevancy and builds on students' prior knowledge to help them connect their informal EBR with more formal, scientific, EBR. Pre and post assessments as well as transcriptions of pre and post student discussions were used to analyze the effectiveness of the instructional strategy.

As required for any research involving human subjects, this study was submitted for review to Portland State University's Human Subjects Research Review Committee (Appendix G), and was found exempt.

\section{Design}


$\begin{array}{llllll}\text { Class } & \mathrm{P} 1 & \mathrm{O} 1 & \mathrm{X} & \mathrm{O} 2 & \mathrm{P} 2\end{array}$

P1= Pre evidence based reasoning survey

O1= Pre instructional strategy discussion

$\mathrm{X}=$ Instructional teaching strategy

O1= Post instructional strategy discussion

P1= Post evidence based reasoning survey

\section{Participants}

Context

The study was conducted in an $8^{\text {th }}$ grade integrated science classroom at Neutral Valley Middle School in Neutral Valley, OR. Neutral Valley is a public middle school serving 1000 students in $6^{\text {th }} 7^{\text {th }}$ and $8^{\text {th }}$ grades. Mr. Tiger who was a qualified secondary science teacher taught the classroom. The class is made up of 40 students, who were all in the $8^{\text {th }}$ grade science class a part of the required curriculum for that year.

Seven of the students spoke a language other than English as their first language. Three students spoke Vietnamese, one spoke Romanian, one Russian, one Spanish, and one Chuukese (spoken in parts of Micronesia). However, only three students are in an ELL program, and there were no students on IEPs in the class. There were 7 TAG Math students and 2 TAG Reading students in the class. Most students were from middle class 
households. $36 \%$ of the student body at Neutral Valley MS qualified for free or reduced-price lunch program (Oregon Department of Education).

Each of the 40 students was given a letter of consent to participate in the study (Appendix G) to take home to be reviewed by parents or guardians; 29 returned signed forms to the teacher before the study began.

In this study there was one group studied, which is the $2^{\text {nd }}$ period $8^{\text {th }}$ grade integrated science classroom described above. All students in the class participated in the activities outlined in this study. Data was collected from all of the 29 participants who turned in completed letters of consent. However, only 20 students completed both the pre and post assessment, so for analysis of the pre and post EBR assessment, only those students' data was used.

The classroom was chosen because it was the classroom and school in which the researcher was doing his student teaching. All students participated in the activities that were the focus of this study. However, data for the study was only collected from students who returned signed consent forms.

During the instruction that was the focus of this study students worked with their table groups, which are determined by the seating arrangement predetermined by Mr. Tiger. During the classroom discussions, the classroom setup was changed to be a circle of chairs centered around the middle of the room, and therefore students will effectively be one large group.

\section{Instructional Activity}


Students were asked to first investigate the EBR that they each do on a daily basis. When they had come to understand the components of claim (evidence and reasoning of their own informal EBR), they started building up to more formal and scientific claims, reasoning, and evidence. Students were guided and supported in both brainstorming and discussion by their peers, the researcher, and the instructor throughout the lesson. Pre and post discussions were also used to help students develop their ability to use EBR, as well as being used to assess the amount of EBR done by students. Through argumentation, students were encouraged to build and support a claim, and back it up with evidence.

Instruction

The students were introduced to the EBR lesson (Appendix D) at the beginning of the period. When the students entered the classroom the first slide of the presentation (Appendix D) was on the projection screen at the front of the room. Using the teaching strategy presentation script (Appendix E), the researcher began the lesson with students seated in their assigned seats. The first 15 minutes of the lesson was a lecture incorporating a few questions to keep students engaged. For the first small group discussion students considered their own experiences using EBR and wrote it on their Connection Sheet (Appendix C). The completion of this guided worksheet included multiple group discussions that were carried out by small groups and the class as a whole. The teacher and 
researcher served as discussion coordinators, walking around to each group during the small group discussion time and the individual work time. The teacher and researcher helped guide students to think reflectively and thoroughly about the questions listed on the "instruction teaching strategy" worksheet. Four student targets were listed as well in the presentation as goals for students for the day. The teacher and researcher focused on these goals during the student discussion and throughout the day. Students were also asked to consider whether they felt that had achieved these goals as they left class, as a way for them to reflect on their experience and increase student learning, as outlined in the research (Holbrook, J. \& Rannikmae, M. 2007).

1. Gain a better understanding of the terms evidence, reasoning and evidence based reasoning.

2. Realize how much EBR you already do.

3. See connections between the EBR you do and the EBR that goes into public policy decisions, or science.

4. Become more comfortable using EBR in normal conversation or discussion.

\section{Instruments}

This study used two methods to collect data on student learning about EBR. First a 24 question online EBR assessment was given to students twice, 
before and after the instructional strategy was implemented. Second student use of EBR was measured during their participation in 2 rounds of class discussion, one prior to instruction and one after.

Table 1: Focus for Each Assessment Method Used in Study

\begin{tabular}{|l|l|}
\hline Method of Assessment & Assessment Focus \\
\hline $\begin{array}{l}\text { Pre evidence based reasoning } \\
\text { assessment } \\
\text { Post evidence based reasoning } \\
\text { assessment }\end{array}$ & $\begin{array}{l}\text { Student familiarity and understanding } \\
\text { of EBR and its components. }\end{array}$ \\
\hline $\begin{array}{l}\text { First large group discussion } \\
\text { Second large group discussion }\end{array}$ & Student ability to use EBR in science \\
\hline
\end{tabular}

Table 1: This table shows each method of assessment, and its correlating focus for each assessment piece in the study.

The Pre and Post EBR Assessment

The researcher-designed pre and post assessment (Appendix A) was administered online and taken by students during class. This assessment is a 24 question Likert type survey that asked students to agree or disagree to 24 prompts on a 1-4 scale. One correlated to a student strongly disagreeing with the statement, 2 correlated with disagree, 3 correlated with agree, and 4 correlated with strongly agreeing. The data was recorded online in a password encrypted folder. Students' names were replaced with numbers before the data was analyzed.

Using background knowledge from teaching and EBR, the researcher developed the questions used in the pre and post assessment. The language 
used in the survey was analyzed and revised by the researcher and the cooperating teacher to be age appropriate for the students. The researcher developed multiple questions aimed at the same understanding target or concept to increase reliability. This approach was used in part because of the difficulty in finding a validated survey that fit within the time allowances of the class period, correlated to the proper student level, or that contained only questions related to EBR.

Researcher Facilitated Classroom Discussion

The two recorded discussions were each approximately 45 minutes in length and consisted of approximately 25 minutes of student responses and 20 minutes of instructions, questions and prompts from the researcher and teacher. The researcher facilitated both discussions with some input from Mr. Tiger. A total of forty student responses were documented from each discussion. This allowed the greatest amount of valid comparison between the two discussions, when quantifying student response types. Roughly 20 minutes of student responses to prompts and questions from the two discussions were reviewed by the researcher and quantified into 4 groups as listed in the rubric below.

EBR rubric: 
1. Claim with reasoning. This student response is simple when a student connects reasoning of any type to a claim. If a student only gave reasoning or claim it was not tabulated.

Example dialogue: "I think parents should have a choice too because it is their child and they can do what they want to them."

2. Evidence NOT directly connected to the reasoning by the student. This student response included claim or reasoning, and evidence, but the student did NOT connect the evidence to the reasoning or claim during the response.

Example dialogue: "I think parents should have a choice because it is their child and they can do what they want to them...children are not responsible adults."

\section{Claim or reasoning with evidence explicitly connected to the reasoning}

or claim by the student. This student response is an example of EBR. The student produced a claim or reasoning, and then directly explained the connection of specific evidence.

Example dialogue: "I think parents should have a choice because it is their child and they can do what they want to them...children are not responsible adults. Adults are given responsibility for their children because they know much better than a child what is good for them"

4. Other. Any other form of response besides those listed above would be recorded under this category. 


\section{Procedure}

Each piece of this study was inserted into the classroom curriculum as time ad teacher permitted. Due to the intrusive nature of the study on current curriculum, the preference for time was given to the curriculum and instruction that was already taking place in the classroom.

This research study evaluated whether the use of a particular teaching strategy could influence the amount of EBR students used in analyzing socioscientific issues (SSI) during large group discussion, as well as how well they understood EBR. The researcher monitored and evaluated student participation in discussion and also used pre and post EBR assessments to determine changes in student understanding of EBR after the teaching strategy was implemented.

Prior to any instruction on EBR, students completed a Likert style EBR survey that was administered online during the beginning of class (Appendix A). The survey asked students about their understanding of EBR, evidence, and reasoning. The same survey (Appendix A) was given at the end of the study as a post assessment to gather data on what changes, if any, occurred in students' understanding of EBR as a result of the instructional strategies.

Three days after completing the initial survey students participated in the first large group discussion. The students were given 2 case studies with follow up questions to answer in their notebooks as homework the night before the discussion (Appendix B). The discussion asked students to debate a current, 
relevant, and curriculum-connected SSI which was represented in the 2 case studies. Each round of discussions was audio recorded for later analysis of the amount of EBR students used in the discussion.

Two days later they completed a 50 minute teacher guided worksheet that incorporated small group discussion meant to illustrate the use of everyday EBR at an informal day to day level. The "connection sheet" (Appendix C) was designed to help scaffold students' understanding of informal EBR towards developing an understanding of more formal EBR. An accompanying presentation (Appendix D) and script (Appendix E) were used by the researcher to conduct the lesson with some reliability.

Five days later the students participated in another SSI based discussion facilitated by the researcher. The students were again given a sheet with 2 case studies with follow up questions that they took home for homework (Appendix F). The discussion was recorded and analyzed, then compared to the first discussion.

Seven days after the second discussion, students were given the post EBR survey (Appendix A), which is the same assessment as the pre EBR assessment.

\section{Results}

This study was guided by the research question: Can explicit teaching of EBR through scaffolding help middle level students gain understanding of and 
the ability to use EBR in a science class? The following section addresses findings related to this research question. The section is broken into two subsections. The first shows the change in students' understanding of EBR as quantified by the pre and post assessments. The second describes students' ability to increase the amount of EBR used in discussion of SSl's in the science classroom.

\section{Change in Students' Understanding of EBR.}

The 24 question Likert style EBR pre and post assessments (Appendix A) were compared and analyzed for gains in student understanding of EBR. Understanding of EBR was analyzed using the class averaged responses to the pre and post assessment. Each pre assessment question's averaged responses were then subtracted from the averaged responses on the corresponding question on the post assessment. Furthermore, questions were grouped into 3 themes: understanding of reasoning, understanding of evidence and understanding of EBR, and analyzed for student understanding changes.

Figures 1 and 2 show learning gains for 22 of the 24 prompts. In Figure 2 the percent change for question 6 "All reasoning is good reasoning", and question 13, "Evidence is something people create" is showed as a positive value to reflect a change toward understanding. However, in response to the prompt "There are many types of reasoning" students' average agreement declined. Students' average agreement with the prompt "There is better and worse evidence" also 
declined. Both of these responses are counter to the correct response.

Figure 3 shows student learning across the themes of student "understanding of reasoning," "understanding of evidence" and "understanding of evidence based reasoning." The three main components of reasoning using evidence are: the claim, the reasoning, and the evidence. Students who understand reasoning and evidence should have a good chance of understanding EBR, as making a claim is necessary for either reasoning or evidence to support each other. Therefore, the questions were categorized along themes of evidence and reasoning, but not claim. "Understanding of Claim" was not a category because the amount of claims students made, without any reasoning connected to them, did not inform this study as to their ability to do EBR.

Class averages for questions under the themes of understanding of reasoning (questions $1,3,4,6,7,8,10$ ), and understanding of evidence (questions $12,13,14,16,18,19,20,22)$ were averaged to showcase the general change in student understanding across those two themes. Only one question from the pre and post assessment (question 24) was used to analyze students' understanding of EBR. The questions that were used in each theme are shown in the corresponding key.

In conclusion, the data from the pre and post assessment showed an overall increase in student understanding of EBR, and its two main components: 
evidence and reasoning. The students' discussion data showed an increase in students' ability using EBR in discussion.

\section{Change in the Amount of EBR Use in Discussion of SSIs}

The two class discussions were audio recorded. The first recording had a total of 40 responses from students. For comparison, the first 40 student responses of the second discussion were analyzed and tabulated into one of the four definitions of responses: claim with reasoning, evidence NOT directly connected to the reasoning by the student, claim or reasoning with evidence explicitly connected to the reasoning or claim by the student, and other.

Table 3 quantifies the data for the amount and type of responses students used when discussing the content connected SSI's in the science classroom. This shows that if students are explicitly taught how to reason with evidence by using connections from their own life, they will be able to use more EBR in discussion.

Figure 5 graphically represents 4 types of student responses to the content connected SSI's in the science classroom. The figure shows a percentage of the 40 responses that were analyzed in the audio recorded discussion, and shows the same conclusions as Table 3.

\section{Discussion}

Increase in Student Understanding of EBR 
The overall results from the 24 question pre and post assessment comparison suggest increased student understanding of reasoning using evidence (Figure 2), and a step toward increasing scientific literacy, as pointed out by the National Science Education Standards (National Research Council, 1996) and the Next Generation Science Standards (National Research Council, 2011). There were only two questions in which the students were more likely to disagree with the statement after the instructional intervention. Students disagreed with the response prompts "There are many types of reasoning" and "There is better and worse evidence" slightly more following the EBR lesson than before it. Both of these responses are considered counter to the intended response. For the prompt "There are many types of reasoning" the percentage change discrepancy is very small $(-1.47 \%)$ and the prompt does not get to the heart of the understanding of EBR or its components, so further discussion is not done.

However, the prompt "There is better and worse evidence" reflects a more important component of understanding of what is meant by evidence than the prompt discussed above, as well as a larger discrepancy $(-4.35 \%)$. If students did not understand that there are better and worse forms of evidence when doing EBR, they would increase their chances of doing EBR poorly. Simply put, reasoning with evidence is not very reliable if poor evidence is used. In future practice, highlighting this in the EBR lesson could be beneficial to student learning. 
In order to look more closely at student responses, pre and post assessment questions were grouped into themes of student "understanding of reasoning"' "understanding of evidence" and "understanding of EBR" (Figure 3). This analysis also suggests strong gains for students in the areas of reasoning (7.67\%) and evidence (8.75\%). Although the data showed a large increase in student understanding of EBR, this result is based on responses to only one question, "I have a clear understanding of what evidence based reasoning is", and therefore the validity of this claim is low. Student understanding of EBR is much better represented by increases in their understanding of evidence and reasoning, and the amount that they using EBR in discussion, than by their claimed understanding from one question on the assessment.

\section{Increases in Usage of EBR}

As shown in Figure 5, there was a strong increase in the amount of EBR used by students in the second discussion (1 response in the first discussion vs. 9 responses in the second). There was also more evidence used by students in the second discussion even though they were not able to vocalize the connection to their claim or reasoning (1 response to 3 responses). This result suggested that scaffolding new knowledge in a way that considers the educational development theory, zones of proximal development (Berk et al, 1995) can help students gain usable new knowledge. 
This suggested that the lesson was an effective way to increase the amount of EBR students used in discussion in the science classroom. However, it should be noted that students were asked to discuss the first genetics related issue while they were still involved in the genetics and heredity unit. The second discussion was done after the unit was completed, possibly giving students a better chance to process what they had learned.

A few questions on the pre assessment directly relate to whether students improved in their ability to use EBR in discussions of socio scientific issues. There was only a $2.17 \%$ increase in students' agreement with the prompt "I use reasoning (how I make sense of things) when I talk to others about my beliefs". Although $2.17 \%$ was an increase, it was not large. However, the reality of actually using EBR versus understanding it could be highlighted using the student responses to the prompt "Explaining my reasoning is difficult" to which students actually agreed with $6.31 \%$ more after they had been taught about EBR. Students were showing that after learning about how to do EBR, they could see it is difficult to do well, and therefore still have barriers to actually being able to use it.

\section{Limitations of the Study}

The timeframe of the study was dictated largely by the time allowances offered within the content of the class and the cooperating teacher. Because of the multiple days in between each piece of this study, the potential for students to 
gain information through other instruction is high. Other teachers at Neutral Valley Middle school focus on making a claim and supporting it with evidence in their classrooms. The researcher spoke with at least three other teachers in the school whose curriculum included how to make and support a claim with evidence, as well as ideas around sound reasoning, in a unit that was running concurrently to the study. This increased the chance that students were gaining understanding of EBR through other outlets than the teaching strategy associated with this study. This reality lessened the validity of the results of this study even though it was effectively good for student learning. Processes like EBR are currently integrated into many different content areas in school because they are important components to teach.

Figure 6 highlights the most interesting outcomes of this study. The questions "I have a clear understanding of evidence based reasoning" and "All beliefs should have evidence to support them" showed strong percentage gains $(20.69 \%, 24.00 \%)$. These two questions were important aspects of what students needed to understand to improve their usage of EBR. It could be argued that as students develop a clearer understanding of EBR they would have an increased ability to use it. To that same point, when a student believes that evidence is an important feature of any belief, they could "naturally" do more EBR whenever they are gaining, losing, or adjusting their own beliefs.

Although we do not see the same large increase in percentage gains in responses to the questions "I use evidence to make decisions every day" and "I 
use reasoning to make decisions everyday", there was a substantial movement (13.79\%, $7.94 \%$ respectively). This suggests students had, or were at least more confident in using EBR. As with many skills, the more time to practice them may be the key to development.

\section{Recommendations for Future Research}

The time for students to practice and develop understanding of EBR was only one class period and therefore the teaching strategy was too short. Teaching students something new needs to include time for them to process and use the new information. Using the SSI based discussions allowed students to practice what they were taught, but it there was only one discussion session after the lesson. For students to be able to hone their ability to use EBR they need to be able to practice it. A similar study to this one, but for a longer duration would also be recommended. Being able to track changes in the amount of EBR students use over time would especially benefit from a longer time frame for research. To be able to track the ability for students to retain, lose, or enhance the process of EB, research should incorporate multiple discussions after an explicit lesson on EBR. Student discussions of content related socio-scientific issues can be used as a formative assessment, data collection, as well as student practice in vocalizing EBR. Beyond making things relevant, which was a focus of this study, students should be able to practice to make themselves more 
comfortable with their own voice in an argument or discussion and be offered more than one chance to show their abilities.

Even though EBR is being taught in other classrooms, after talking with other teachers, I realized that students are not getting to use their EBR in discussion. Incorporating discussion based EBR into classrooms of any sort, would be a general recommendation for teachers. By using the knowledge being taught to students in discussion, they may gain confidence in the power of EBR as a tool to communicate their ideas.

Late into the research the researcher recognized that a focus on the claim itself was missing from this study. The students were familiar with creating a claim due its usage in the science classroom as well as other content areas. Using students' familiarity with how to make a claim would have benefited this study by increasing the amount of knowledge the students' were using that was prior knowledge, and would have allowed for a stronger foundation to build new knowledge with.

Research into what makes students trust the power of EBR would be very beneficial for science and especially science literacy. Future research into students' and adults' beliefs in EBR would be very informative as to how to teach it so that students carry it with them into their future. 
Figure 1: Students Responses to Individual Pre and Post Assessment

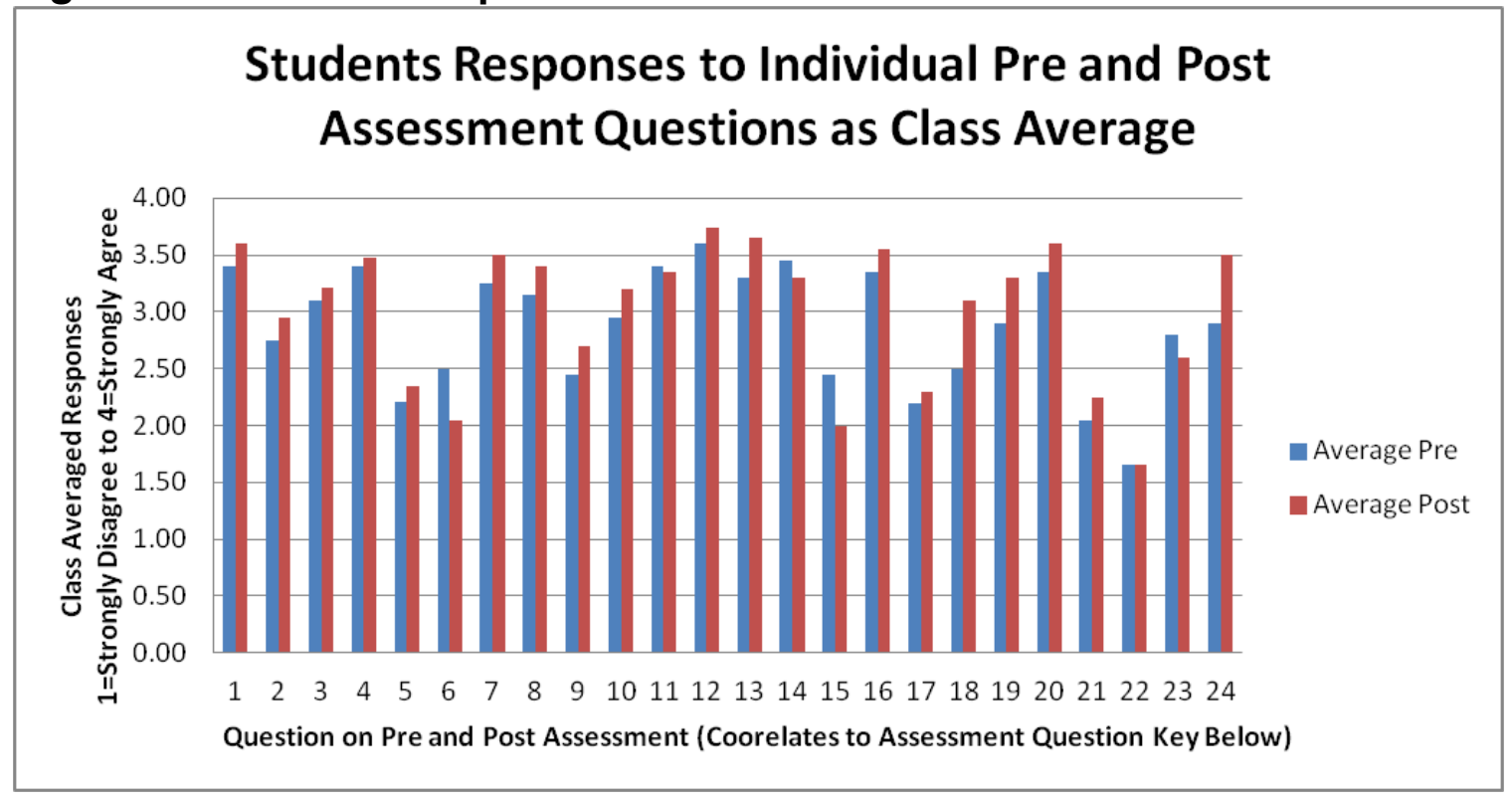

Figure 1 Graphical representation student responses to individual questions on pre and post assessment represented as class averaged numerical values that correlate to responses on assessment. $1=$ Strongly Disagree 2=Disagree 3=Agree 4=Strongly Agree

\section{Figure 1 Corresponding Question Key}

1 I know how to reason (make sense of things) well

2 My gut instinct is usually right

3 It is possible to use/do bad reasoning

4 I use reasoning (how I make sense of things) when I talk to others about my beliefs

5 Explaining my reasoning is difficult

6 All reasoning is good reasoning

7 I use reasoning to make decisions

8 I use reasoning to make decisions everyday

9 Others always understand my reasoning

10 Reasoning is a skill that needs development and practice

11 There are many types of reasoning

12 It is easier to believe what people say, when they support their ideas with evidence

13 I have a clear understanding of what good evidence is

14 There is better and worse evidence

15 Evidence is something people create

16 When I make an important decision, evidence is important to me

17 All evidence is good evidence

18 All beliefs should have evidence to support them

19 I use evidence to make decisions everyday

20 Evidence is useful everyday

21 Evidence is mainly useful in science class

22 All evidence comes from science

23 People are naturally good at using reasoning with evidence

24 I have a clear understanding of what "evidence based reasoning" is 
Figure 2: Percent Change in Class Averaged Pre and Post Assessment

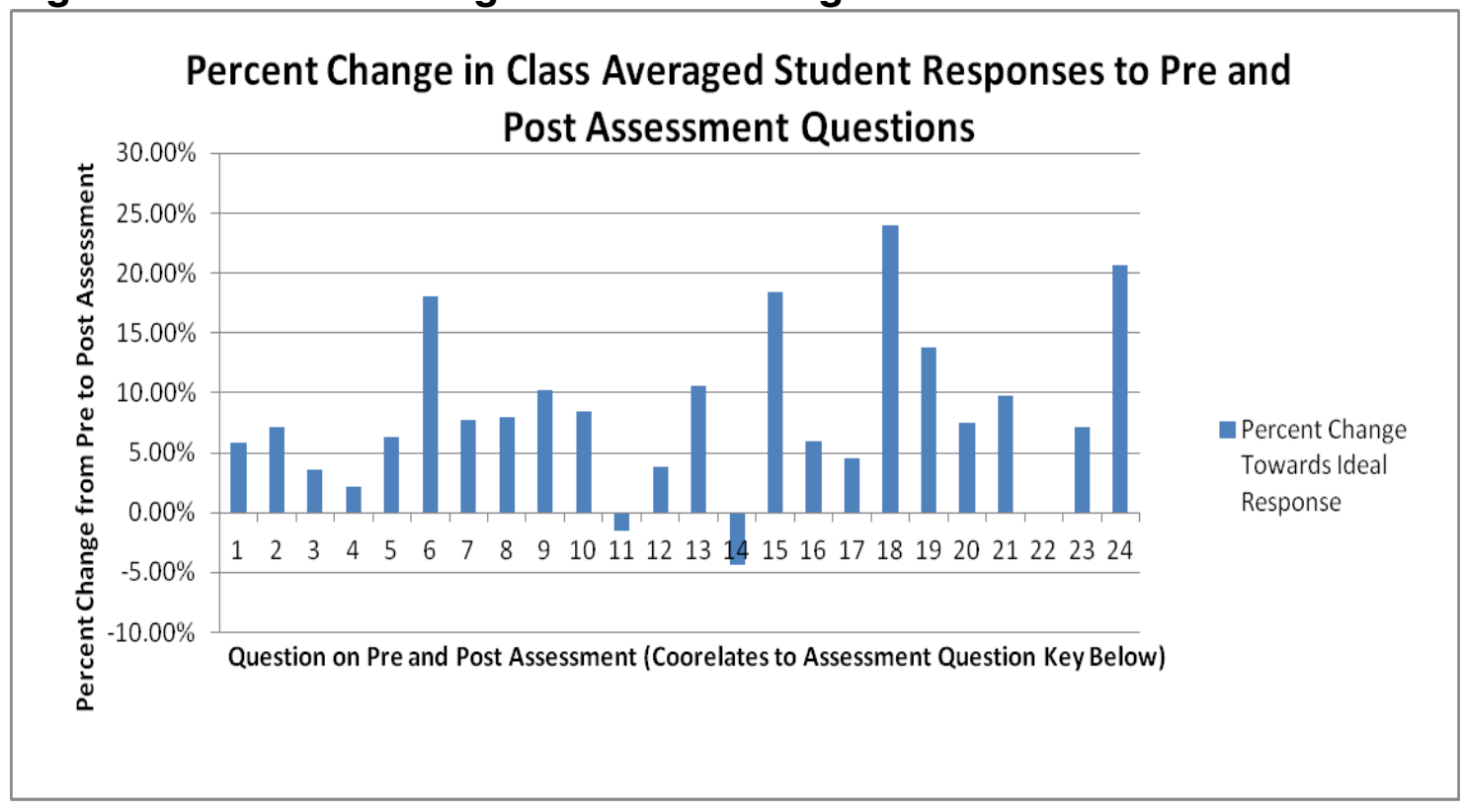

Figure 2 Graphical representation of class averaged student responses to individual questions on pre and post assessment. Percent change correct for negative values on question where that was the intended direction to show learning gains.

\section{Figure 2 Corresponding Question Key}

1 I know how to reason (make sense of things) well

2 My gut instinct is usually right

3 It is possible to use/do bad reasoning

4 I use reasoning (how I make sense of things) when I talk to others about my beliefs

5 Explaining my reasoning is difficult

6 All reasoning is good reasoning

7 I use reasoning to make decisions

8 I use reasoning to make decisions everyday

9 Others always understand my reasoning

10 Reasoning is a skill that needs development and practice

11 There are many types of reasoning

12 It is easier to believe what people say, when they support their ideas with evidence

13 I have a clear understanding of what good evidence is

14 There is better and worse evidence

15 Evidence is something people create

16 When I make an important decision, evidence is important to me

17 All evidence is good evidence

18 All beliefs should have evidence to support them

19 I use evidence to make decisions everyday

20 Evidence is useful everyday

21 Evidence is mainly useful in science class

22 All evidence comes from science

23 People are naturally good at using reasoning with evidence

24 I have a clear understanding of what "evidence based reasoning" is 
Figure 3: Themed Student Understanding Gains

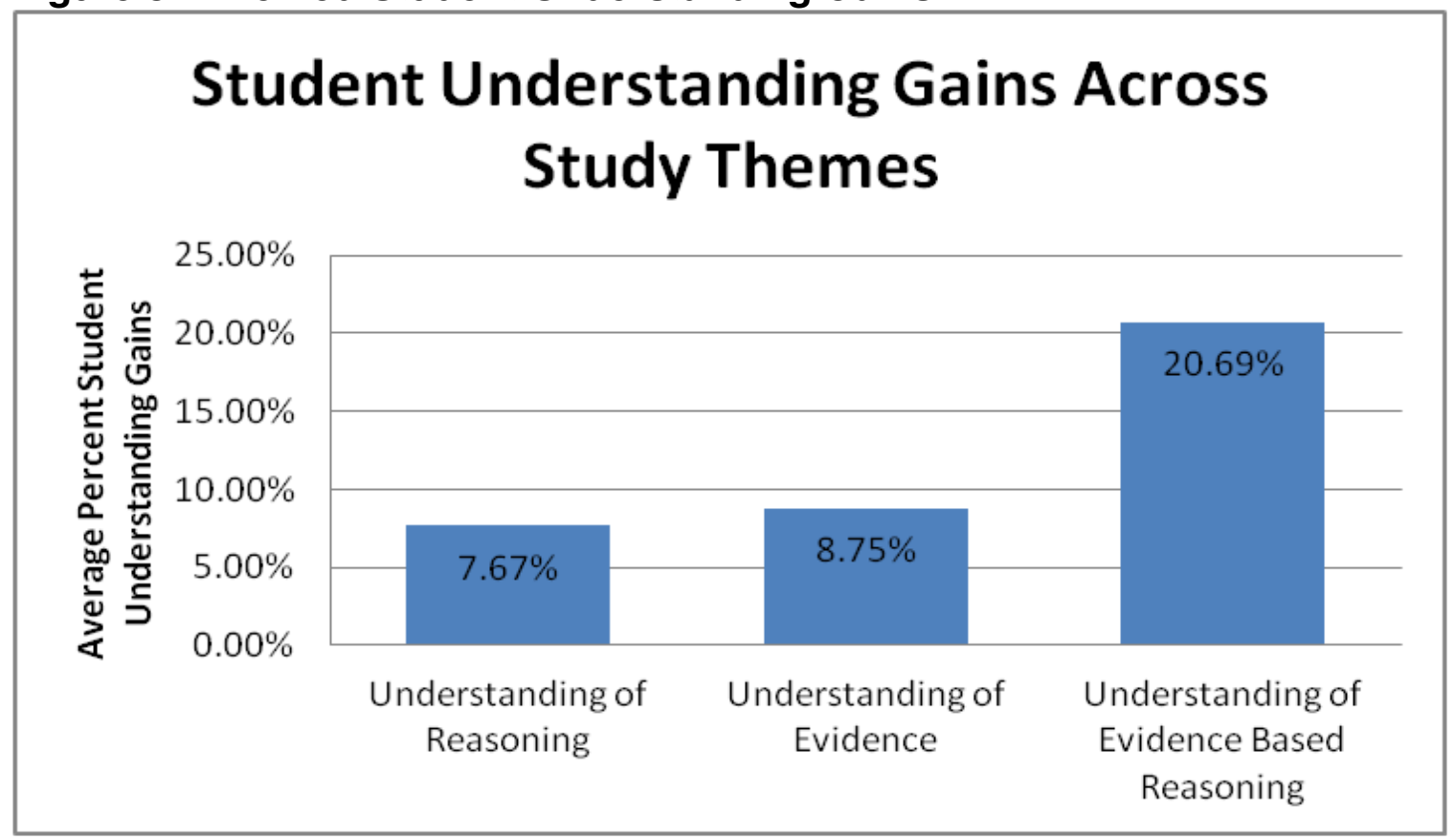

Figure 3 Graphical representation of class averaged student responses to individual questions on pre and post assessment. (*Percent change recorded as absolute value on questions where a negative percent change represented students understanding gain.)

Figure 3 Corresponding Question Key

Understanding of Reasoning included average percent change of the following questions

- I know how to reason (make sense of things) well

- It is possible to use/do bad reasoning

- I use reasoning (how I make sense of things) when I talk to others about my beliefs

- All reasoning is good reasoning

- I use reasoning to make decisions

- I use reasoning to make decisions everyday

- $\quad$ Reasoning is a skill that needs development and practice

Understanding of Evidence included average percent change of the following questions

- It is easier to believe what people say, when they support their ideas with evidence

- I have a clear understanding of what good evidence is

- There is better and worse evidence

- When I make an important decision, evidence is important to me

- All beliefs should have evidence to support them

- I use evidence to make decisions everyday

- $\quad$ Evidence is useful everyday

- $\quad$ All evidence comes from science

Understanding of Evidence Based Reasoning included average percent change of the following question

- I have a clear understanding of what "evidence based reasoning" is 
Figure 4: Informative Student Responses

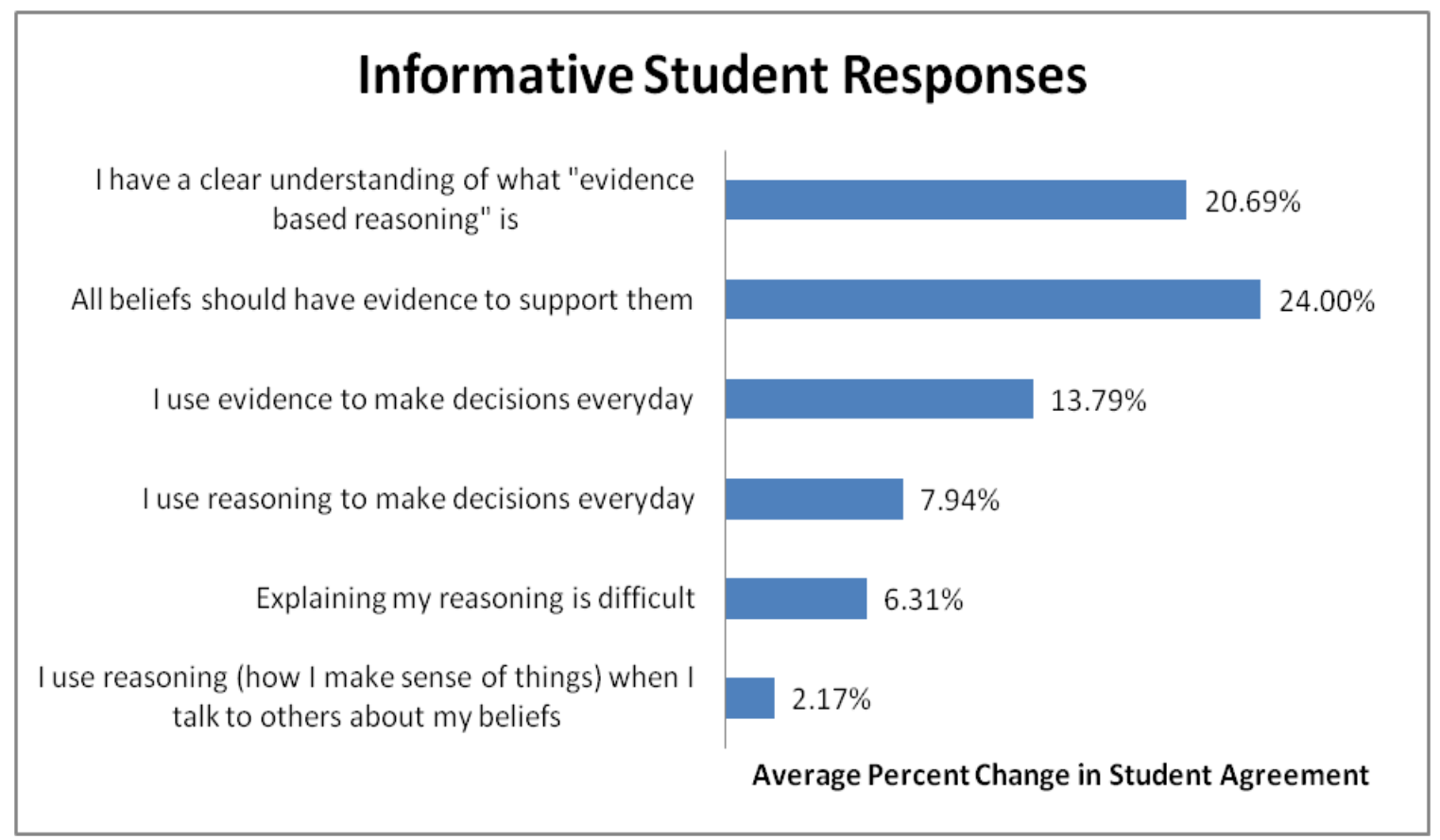

Figure 4 These 6 questions are highlighted as the most informative individual questions of the pre and post EBR assessment analysis. 
Figure 5: Type of Student Responses During Discussions

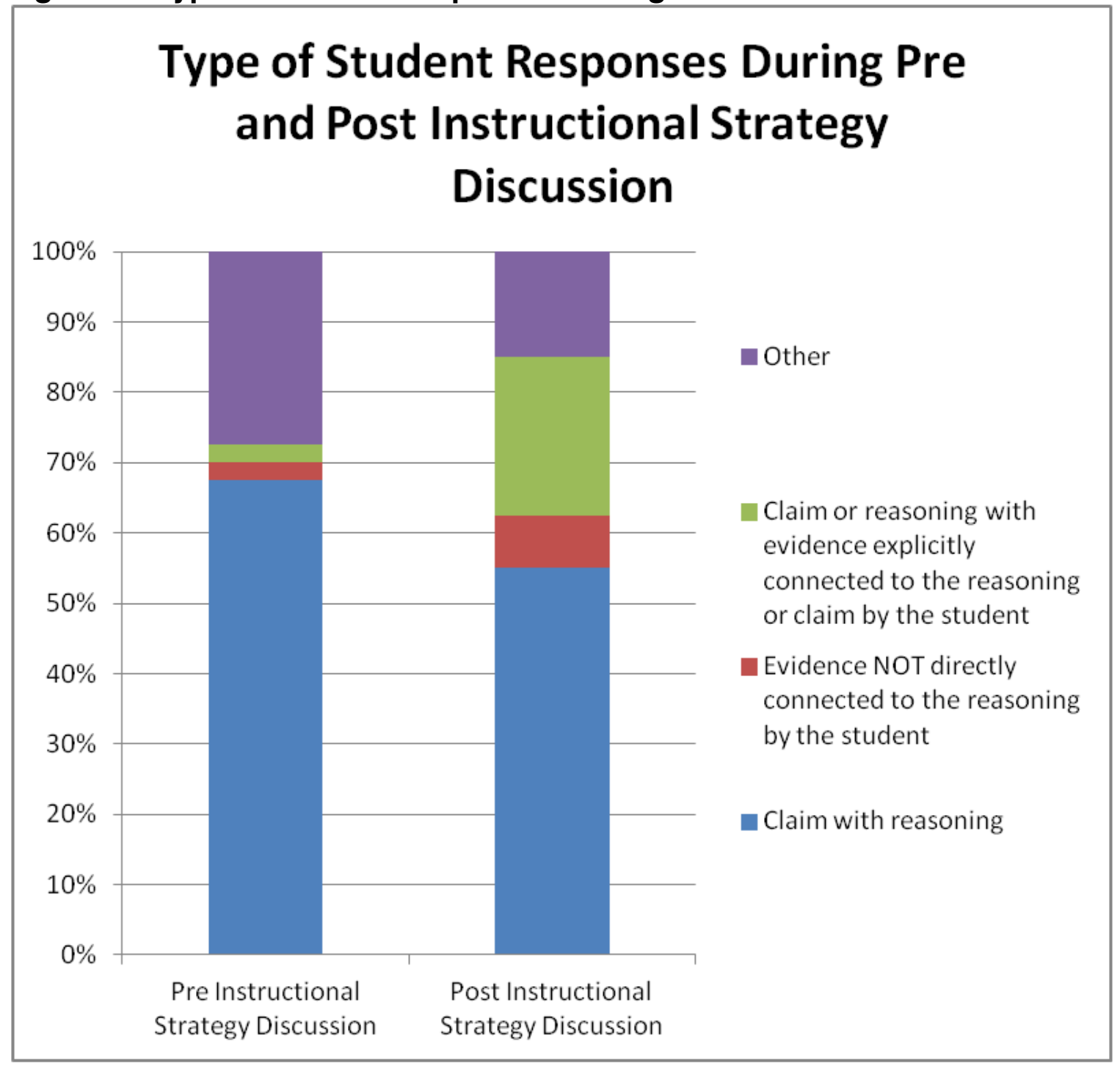

Figure 5 partitions the type of student responses into the 4 categories: Claim with reasoning, Evidence not directly connect to the reasoning by the student and claim or reasoning with evidence explicitly connected to the reasoning or claim by the student, and other. 
Table 1: Focus for Each Assessment Method Used in Study

\begin{tabular}{|l|l|}
\hline Method of Assessment & Assessment Focus \\
\hline $\begin{array}{l}\text { Pre evidence based reasoning } \\
\text { assessment } \\
\text { Post evidence based reasoning } \\
\text { assessment }\end{array}$ & $\begin{array}{l}\text { Student familiarity and understanding } \\
\text { of EBR and its components. }\end{array}$ \\
\hline $\begin{array}{l}\text { First large group discussion } \\
\text { Second large group discussion }\end{array}$ & Student ability to use EBR in science \\
\hline
\end{tabular}

Table 1: This table shows each method of assessment, and its correlating focus for each assessment piece in the study. 
Table 2: Data Collected from Pre and Post Instructional Strategy Discussions

\begin{tabular}{|l|l|l|l|l|}
\hline & $\begin{array}{l}\text { Total } \\
\text { student } \\
\text { comments }\end{array}$ & $\begin{array}{l}\text { Claim with } \\
\text { reasoning }\end{array}$ & $\begin{array}{l}\text { Evidence NOT } \\
\text { directly connected } \\
\text { to the reasoning by } \\
\text { the student }\end{array}$ & $\begin{array}{l}\text { Claim or reasoning with } \\
\text { evidence explicitly } \\
\text { connected to the } \\
\text { reasoning or claim by the } \\
\text { student }\end{array}$ \\
\hline $\begin{array}{l}\text { Discussion } \\
\text { One }\end{array}$ & 40 & 27 & 1 & 1 \\
\hline $\begin{array}{l}\text { Discussion } \\
\text { Two }\end{array}$ & 40 & 22 & 3 & 9 \\
\hline
\end{tabular}




\section{References}

Bell, R. G. (2003). Understandings of the Nature of Science and Decision Making on Science and Technology Based Issues. Science Education, 87(3), 352.

Berk, L. E., \& Winsler, A. (1995). "Vygotsky's approach to development". In Scaffolding children's learning: Vygotsky and early childhood education. Washington: National Association for the Education of Young Children.

Holbrook, J. \& Rannikmae, M. (2007). The Nature of Science Education for Enhancing Scientific Literacy. International Journal Of Science Education, 29(11), 1347-1362.

Michaels, S., O'Connor, C., \& Resnick, L. (January 01, 2008). Deliberative Discourse Idealized and Realized: Accountable Talk in the Classroom and in Civic Life. Studies in Philosophy and Education, 27, 4, 283-297.

Michaels, S., Shouse, A. W., Schweingruber, H. A., \& National Research Council (U.S.). (2008). Ready, set, science!: Putting research to work in K-8 science classrooms. Washington, D.C: National Academies Press.

National Research Council (U.S.). (1996). National Science Education Standards: Observe, interact, change, learn. Washington, DC: National Academy Press.

National Research Council. (2011). A Framework for K-12 Science Education: Practices, Crosscutting Concepts, and Core ideas. Washington, DC: The National Academy Press. Prepublication.

Oregon Department of Education. (2011). Beaverton School District Annual Statistics [data file]. Retrieved from http://www.beaverton.k12.or.us/pdf/dist/res_rep/dist_res_rep_bsd_statistic s.pdf

Osborne, J. (April 23, 2010). Arguing to Learn in Science: The Role of Collaborative, Critical Discourse. Science,328, 5977, 463.

Oulton, C. M. (2004). Reconceptualizing the teaching of controversial issues. International Journal Of Science Education, 26(4), 411-423.

Ratcliffe, M. (1997). Pupil decision-making about socio-scientific issues within the science curriculum. International Journal of Science Education, 19, 2, 167182.

Ruiz-Primo, M. A., Li, M., Tsai, S.-P., \& Schneider, J. (May 01, 2010). Testing one premise of scientific inquiry in science classrooms: Examining 
students' scientific explanations and student learning. Journal of Research in Science Teaching, 47, 5, 583-608.

Sadler, T. D., \& Zeidler, D. L. (January 01, 2005). The Significance of Content Knowledge for Informal Reasoning regarding Socioscientific Issues: Applying Genetics Knowledge to Genetic Engineering Issues. Science Education, 89, 1, 71-93.

Smith, III J. P., [CS1] diSessa, A. A., \& Roschelle, J. (January 01, 1994). Misconceptions Reconceived: A Constructivist Analysis of Knowledge in Transition. The Journal of the Learning Sciences, 3, 2, 115-163.

Zeidler, D. L., Applebaum, S., Callahan, B. E., \& Sadler, T. D. (January 01, 2009). Advancing reflective judgment through socioscientific issues. Journal of Research in Science Teaching, 46, 1, 74-101.

Zohar, A., \& Nemet, F. (January 01, 2002). Fostering Students' Knowledge and Argumentation Skills through Dilemmas in Human Genetics. Journal of Research in Science Teaching, 39, 1, 35-62. 


\section{Appendices}

\section{Appendix A: Evidence Based Reasoning Pre/Post Assessment}

Please carefully read each question. Then fill in the bubble that best represents how much you agree with the statement.

1= Strongly Disagree 2= Disagree 3= Agree 4=Strongly Agree

I know how to reason (make sense of things) well

$$
\begin{array}{llll}
1 & 2 & 3 & 4
\end{array}
$$

Strongly Disagree $\bigcirc \quad \bigcirc \quad$ Strongly Agree

My gut instinct is usually right

$$
\begin{array}{llll}
1 & 2 & 3 & 4
\end{array}
$$

Strongly Disagree $\quad C \quad C \quad$ Strongly Agree

It is possible to use/do bad reasoning

$$
\begin{array}{llll}
1 & 2 & 3 & 4
\end{array}
$$

Strongly Disagree $\quad \bigcirc \quad$ Strongly Agree

I use reasoning (how I make sense of things) when I talk to others about my beliefs

$$
\begin{array}{llll}
1 & 2 & 3 & 4
\end{array}
$$

Strongly Disagree $\bigcirc \quad \bigcirc \quad$ Strongly Agree

Explaining my reasoning is difficult

$$
\begin{array}{llll}
1 & 2 & 3 & 4
\end{array}
$$

Strongly Disagree $\bigcirc \quad$ Strongly Agree

All reasoning is good reasoning

$$
\begin{array}{llll}
1 & 2 & 3 & 4
\end{array}
$$




\section{Strongly Disagree $\quad$ Strongly Agree}

I use reasoning to make decisions

$\begin{array}{llll}1 & 2 & 3 & 4\end{array}$

Strongly Disagree $\quad 0 \quad$ Strongly Agree

I use reasoning to make decisions everyday

$$
\begin{array}{llll}
1 & 2 & 3 & 4
\end{array}
$$

Strongly Disagree $\quad 0 \quad 0 \quad$ Strongly Agree

Others always understand my reasoning

$$
\begin{array}{llll}
1 & 2 & 3 & 4
\end{array}
$$

Strongly Disagree $\quad C \quad$ Strongly Agree

It is easier to believe what people say, when they support their ideas with evidence $\begin{array}{llll}1 & 2 & 3 & 4\end{array}$

Strongly Disagree $\quad C \quad$ Strongly Agree

I have a clear understanding of what good evidence is

$$
\begin{array}{llll}
1 & 2 & 3 & 4
\end{array}
$$

Strongly Disagree $\quad$ C $\quad$ Strongly Agree

There is better and worse evidence

$$
\begin{array}{llll}
1 & 2 & 3 & 4
\end{array}
$$

Strongly Disagree $\quad$ C $\quad$ Strongly Agree

Evidence is something people create

$\begin{array}{llll}1 & 2 & 3 & 4\end{array}$


Strongly Disagree $\quad \bigcirc \quad \bigcirc$ Strongly Agree

When I make an important decision, evidence is important to me $\begin{array}{llll}1 & 2 & 3 & 4\end{array}$

Strongly Disagree $\quad$ C $\quad$ Strongly Agree

All evidence is good evidence

$\begin{array}{llll}1 & 2 & 3 & 4\end{array}$

Strongly Disagree $\quad C \quad C \quad$ Strongly Agree

All beliefs should have evidence to support them

$$
\begin{array}{llll}
1 & 2 & 3 & 4
\end{array}
$$

Strongly Disagree $\quad C \quad$ Strongly Agree

I use evidence to make decisions everyday

$$
\begin{array}{llll}
1 & 2 & 3 & 4
\end{array}
$$

Strongly Disagree $\quad C \quad$ Strongly Agree

Reasoning is a skill that needs development and practice

$$
\begin{array}{llll}
1 & 2 & 3 & 4
\end{array}
$$

Strongly Disagree $\quad$ C $\quad$ Strongly Agree

There are many types of reasoning.

$$
\begin{array}{llll}
1 & 2 & 3 & 4
\end{array}
$$

Strongly Disagree $\quad$ C $\quad$ Strongly Agree

Evidence is useful everyday

$$
\begin{array}{llll}
1 & 2 & 3 & 4
\end{array}
$$




\section{Strongly Disagree $\quad C \quad C \quad$ Strongly Agree}

People are naturally good at using reasoning with evidence

$$
\begin{array}{llll}
1 & 2 & 3 & 4
\end{array}
$$

Strongly Disagree $\quad C \quad$ Strongly Agree

Evidence is mainly useful in science class

$$
\begin{array}{llll}
1 & 2 & 3 & 4
\end{array}
$$

Strongly Disagree $\quad C \quad C \quad$ Strongly Agree

All evidence comes from science

$$
\begin{array}{llll}
1 & 2 & 3 & 4
\end{array}
$$

Strongly Disagree $\quad C \quad @ \quad$ Strongly Agree

I have a clear understanding of what "evidence based reasoning" is

$$
\begin{array}{llll}
1 & 2 & 3 & 4
\end{array}
$$

Strongly Disagree $\quad \bigcirc \quad \bigcirc \quad \bigcirc \quad$ Strongly Agree 


\section{Appendix B: Pre Teaching Strategy Discussion Topics}

\section{CASE STUDY 1}

Patenting of Genes

Dr. Lydia Mendoza and her company, Genmania, have spent years working to identify how the gene for albinism works. The mutation in this gene causes no pigment to be produced in the hair, skin or eyes. Identifying the gene would open the door to curing the condition. Finally, her team succeeds.

But the years spent on research were expensive. One way to make back that money is to patent the gene that team members just identified. Then, anyone who wanted to develop either treatments or tests would have to pay a fee to use the gene.

When a patent is submitted to the government, the company must prove that the item to be patented is original and patentable.

\section{Questions}

1. What do you think about patenting a gene that already exists in the human body?

2. Should the government allow this gene to be patented?

Why or why not?

3. Some think that genes should not be patented because they are a medical discovery and not an invention, and everyone should be allowed to use the information without paying. What do you think?

4. If, in the future, Genmania develops a test for this gene, should they be allowed to patent the test?

Why or why not?

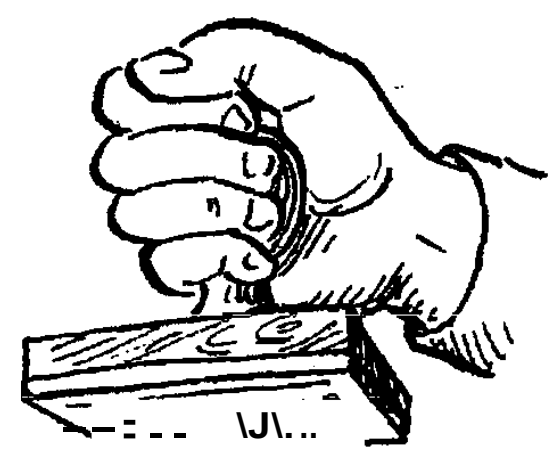




\section{CASE STUDY 2}

\section{Therapy vs. Enhancement}

Scientists in New Jersey have recently inserted a gene to create a mouse with increased capacity for learning and memory-basically, a gene that increased the animal's intelligence quotient (IQ).

Normal, average human IQ is about 100.' Sometimes IQ can go way up to $130 \mathrm{~s}, 140$ s, 150 s, etc. An IQ of about 70 or below is considered to indicate mental disability.

Although currently highly theoretical and perhaps impossible, it might in the far future become possible to insert a human gene identified through the Human Genome Project to increase human IQ by 30 points. Consider these two scenarios:

A couple has a 5-year-old son with Down syndrome with an IQ of 70. They want to use gene therapy to insert a gene to increase the IQ of their son from 70 to 100 in order for him to function normally. This is considered gene therapy, where technology is used to help a person function better.

A second couple has a 5-year-old son with an IQ of 120. They want to use the technology to bring their son's IQ up to 150. They feel he would then have a better chance to get accepted to a more prestigious university. This is called gene enhancement, where technology is used to help a person who is already at or above functioning levels to enhance a particular characteristic even more.

Questions

1. Should gene technology be used for gene therapy?

Why or why not?

2. Should gene technology be used for gene enhancement? Why or why not?

3. Who should decide? Parents? Doctors? Government?

Society? Someone else? 
Appendix C: Evidence Based Reasoning Connection Sheet

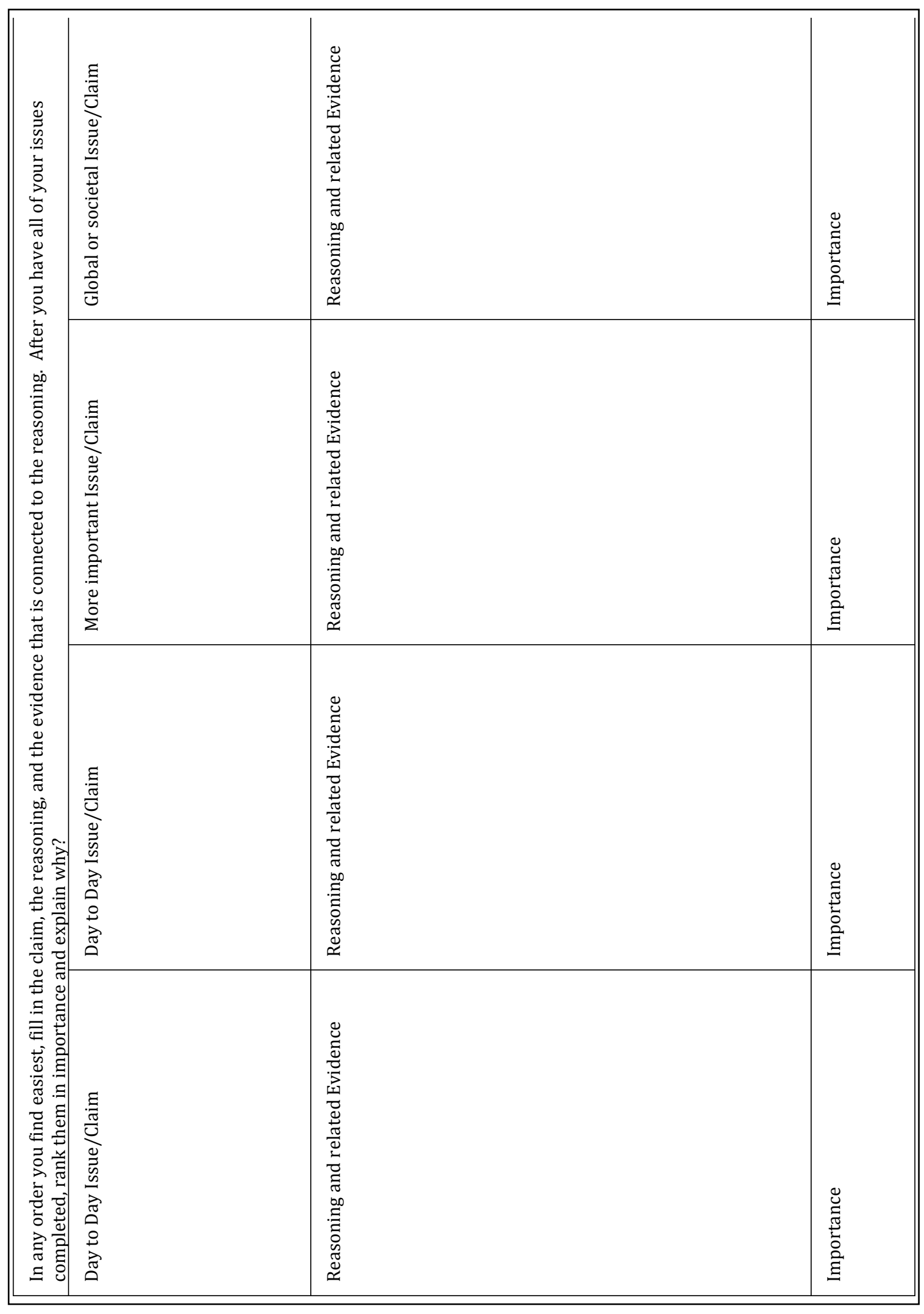




\section{Appendix D: Teaching Strategy Presentation}

\section{Evidence Based Reasoning}

...or reasoning using evidence

\section{Student Targets}

1. Gain a better understanding of the terms evidence, reasoning and evidence based reasoning.

2. Realize how much evidence based reasoning you already do.

3. See connections between the evidence based reasoning you do and the evidence based reasoning that goes into public policy decisions, or science.

4. Become more comfortable using evidence based reasoning in normal conversation or discussion. 


\section{Definitions}

Evidence based reasoning: Reasoning using evidence

Reasoning: when you give a reason for having an opinion or position or hypothesis.

Evidence: what you use to back yourself up

Another way of saying it is, evidence is what makes you seem reasonable to the rest of us.

\section{Mr. Chandler...this seems like kid stuff}

The reason I am teaching you this is because adults (people who vote, make laws, drive around, tell you they know stuff) are generally not very good at using evidence based reasoning. When people make decisions they usually just trust their gut, or stick to some principle that they feel is right without looking at evidence. Evidence is rarely talked about when discussing things like climate change, gay rights, the economy, minimum wage, gun laws, etc. which are things that can have a really big impact on other peoples lives.

Is that reasonable enough to continue? 


\section{Example:}

Issue: You want eat your pop tart before catching the bus. Your mom wants you to hurry up.

Reasoning: You have time to eat it.

Evidence: The clock clearly states that there is 8 minutes before you need to catch a bus. You have eaten many pop tarts before, and you know you can do it in less than 8 minutes.

\section{5 minutes (individual)}

Work individually on your own Evidence Based Reasoning Connection Chart

Fill in one Issue, Reasoning and Evidence 


\section{2 minutes (shoulder partner)}

Pair share with your shoulder partner.

Offer suggestions for your partner.

Discuss how you could improve the reasoning or evidence to strengthen each others position.

\section{3 minutes (class)}

Share out as a class and offer up suggestions and help people define what is reasoning, and what is evidence 


\section{0 minutes (table groups)}

Fill in the rest of the issues on the Evidence Based Reasoning Connection Chart

-Work in Table Groups

-You can share Issues, but come up with your own Evidence, Reasoning and Importance

\section{Debrief $10 \mathrm{~min}$ (class)}

Bring your papers to the front.

I will pick examples and the class can help identify the reasoning and evidence. 


\section{Debrief Questions}

Choose two issues. Look at the reasoning and evidence. What are the similarities? What are the differences?

\section{Debrief Questions}

Are there better and worse ways of reasoning?

Are there better and worse types of evidence? 


\section{Debrief Questions}

Is being able to reason well easy to do all the time?

What gets in the way of good reasoning?

\section{Debrief Questions}

Why do most people not use evidence based reasoning?

Should we take them as seriously? 


\section{Student Targets}

In your composition books, rate how well each of these targets were met for you. 1-5. What was one thing you found very interesting? What was one thing you struggled with?

1. Gain a better understanding of the terms evidence, reasoning and evidence based reasoning.

2. Realize how much evidence based reasoning you already do.

3. See connections between the evidence based reasoning you do and the evidence based reasoning that goes into public policy decisions, or science.

4. Become more comfortable using evidence based reasoning in normal conversation or discussion. 


\section{Appendix E: Teaching Strategy Presentation Script}

SLIDE 1

$\mathrm{Hi}$ there. Today I would like to help you understand what evidence based reasoning really is. Evidence based reasoning is what scientist use to help support for their ideas. What everyone wants you to believe in as middle school students' is that EBR is too tough or complex for you to do. Mr. Wang and I disagree.

It just so happens that you use evidence based reasoning all the time in your daily life. If you didn't you would not have made it this far! Don't believe me? Well let's see if we can find some evidence to back up that claim, and to see if what I am saying is reasonable.

SLIDE 2

First let me start with targets for the day.

*read targets

Ask students if they have questions.

SLIDE 3

Next let me define the term...

Evidence based reasoning: Reasoning using evidence.

Ok are we all together? Great, so then maybe you are asking, what is reasoning? What is evidence? Why do we use them? All really are great questions. Basically,

\section{Reasoning is when you give a reason for something, such as an opinion or position or theory. \\ Evidence is what you use to back yourself up.}

SLIDE 4

You may be asking, Mr. Chandler, this stuff seems obvious.

The reason I am teaching you this is because adults (people who vote, make laws, drive around, tell you they know stuff, and people you are going to be one day) are generally not very good at using EBR. When people make decisions they usually just trust their gut, or stick to some principle that they feel is right without looking at the 
evidence. Evidence is rarely talked about when discussing things like climate change, gay rights, the economy, minimum wage, gun laws, etc. which are the that can have a really big impact on other people's lives.

SO, starting with you guys...lets change that!!!

SLIDE 5

Let me give you a simple example of evidence based reasoning: Most of us claim that we need to get to school before it starts. Reasoning for this might be that your parent or guardian will yell at you. Evidence for that would be when you have been late in the past someone has yelled at you every time.

Continuing with that situation, so there you are munching your pop tart and you check the clock to see you have 8 minutes left to chew your pop tart. Here you use the clock as evidence to support your claim that you have 8 minutes to eat your pop tart in peace. If your parent or guardian started yelling at you could use this evidence to back yourself up and tell her, "Hey, look at the clock mom, I have 8 minutes until the bus arrives, so be cool." Now if you did not have this evidence your mom would just end up yelling at each other about your unfounded opinions... and we all know that does not make for a good discussion.

HAND OUT THE CONNECTION SHEET

SLIDE 6

(10 min) Individual: Using the Evidence Based Reasoning Connection Sheet try to come up with a few issues that you have that you use reasoning for (such as getting to the bus on time). Think of things you care about. Think of things that really get you pumped or make you happy... or things that you finds really annoying or super stupid in your mind... and then explore why. That will be your reasoning. Then see what evidence you have for feeling that way.

TIP: Reasoning and evidence often is hard to separate when dealing with everyday things, but it seems to get easier to separate when you starting talking about bigger issues, like the ones that you discussed in the discussion group recently.

SLIDE 7

Pair-share your issue and reasoning. '1 min per partner

- Have each partner offer suggestions.

- Group discussion to make sure we are all on the same page. 
SLIDE 8

- Three pair share groups share out. The class helps them define reasoning and evidence as well as suggest other types of evidence or reasoning that could be used. Helpful questions might be, does that evidence support the reasoning or claim? Does that evidence make the reason more or less valid?

(10 min) Small Group: Please fill in the rest of your worksheet with 3 other examples. One that is a simple day to day issue, one that is a more important issue and one that you think has really big consequences to lots of people. You are allowed to use each other's issue ideas, but produce your own evidence and reasoning and choose your own ranking of importance. If you finish early tell you table groups some of the most meaningful things to you and why.

(10 min)LARGE GROUP: Collect the Connection Sheets and choose a few at random and anonymously to read out-loud and analyze with any of the questions on the slides. Discuss evidence based reasoning from an informal to a formal level.

Optional Focus Questions for elaboration:

- What connections do you see between the issues?

- What does it require to do evidence based reasoning?

- How is what scientists do different from what you do every day? How is it the same?

- Are there better and worse ways of reasoning?

- Are there better and worse types of evidence?

- Why is good reasoning worth taking the time to do now and throughout your life?

- Why should it matter if someone uses bad reasoning and someone uses good reasoning, can't we all just do whatever we want?

- Is being able to reason well easy to do all the time? What gets in the way of good reasoning? 


\section{Appendix F: Post Teaching Strategy Discussion Topics Case Study 1}

Aggressive Behavior

Scientists in Russia have been studying aggressive behavior in foxes for almost a half generation. They have been able to identify the genes that are responsible for aggressive behaviors in foxes. They also realized that when that gene is selected for, there are other changes that occur in the foxes related to color of their coat, and tail shape.

At the pace that genetics is progressing, it is very likely that an aggressive gene or genes could be identified in humans. If the gene that were responsible for aggressive behavior were identified as the genotype aa, many questions of what to do with people who carry(Aa) or express the gene(aa) would need to be addressed.

1. As a society is it ok to have people that are aggressive?

2. What do we do to people that are aggressive currently? Should that change if we could identify the gene that is responsible for it?

3. If you were a carrier of the gene, but did not express the gene (i.e. aa is the expression of the aggressive phenotype, but you have Aa, so you do not express the aggressive behavior, but your kids might). Should you be allowed to reproduce?

4. If you had the gene, how would you like to be treated?

5. If it was shown that $90 \%$ of those people in jail had the gene, what should be done?

6. Could gene therapy be an effective treatment? 


\section{Case Study 2}

Therapy vs. Enhancement

Scientists in New Jersey have recently inserted a gene to create a mouse with increased capacity for learning and memory-basically, a gene that increased the animal's intelligence quotient (IQ).

Normal, average human 10 is about 100. Sometimes IQ can go way up to 130s, 140s, 150s, etc. An IQ of about 70 or below is considered to indicate mental disability.

Although currently highly theoretical and perhaps impossible, it might in the far future become possible to insert a human gene identified through the Human Genome Project to increase human IQ by 30 points. Consider these two scenarios:

A couple has a 5-year-old son with Down syndrome with an IQ of 70. They want to use gene therapy to insert a gene to increase the IQ of their son from 70 to 100 in order for him to function normally. This is considered gene therapy, where technology is used to help a person function better.

A second couple has a 5-year-old son with an IQ of 120. They want to use the technology to bring their son's IQ up to 150. They feel he would then have a better chance to get accepted to a more prestigious university. This is called gene enhancement, where technology is used to help a person who is already at or above functioning levels to enhance a particular characteristic even more.

Questions

1. Should gene technology be used for gene therapy?

Why or why not?

2. Should gene technology be used for gene enhancement? Why or why not?

3. Who should decide? Parents? Doctors? Government?

Society? Someone else? 


\section{Appendix G: HSRCC Review Exemption Form \\ Portland State University HSRRC Memorandum}

To: Erol Chandler and Liza Finkel

From: HSRRC 2012

Date: November 2, 2012

Re: HSRRC exempt review of your application titled, "Gaining scientific evidencebased reasoning skills through understanding of prior, well used and reliable small time evidence-based reasoning" (HSRRC Proposal \#122348)

Your proposal is exempt from further Human Subjects Research Review Committee review, and you may proceed with the study.

Even with the exemption above, it was necessary by University policy for you to notify this Committee of the proposed research, and we appreciate your timely attention to this matter. If you make changes in the research protocol, the Committee must be notified in writing, and changes must be approved before being implemented.

If you have questions or concerns, please contact the HSRRC at 503-725-2243 or visit us at Research and Strategic Partnerships, Market Center Building, $6^{\text {th }}$ Floor.

cc: $\quad$ Andrea Haack 